\title{
Polisakaridoetan oinarritutako hidrogelak eta haien aplikazioak biomedikuntzan
}

\author{
(A review of polysaccharide based hydrogels and its application \\ in biomedicine)
}

\author{
Mikel Mendibe, Ainhoa Lejardi*, Jose-Ramon Sarasua \\ Euskal Herriko Unibertsitatea \\ ZIBIO ikertaldea \\ Meatze eta Metalurgia Ingeniaritza eta Materialen Zientzia Saila eta POLYMAT \\ Bilboko Ingeniaritza Eskola (EIB/BIE 1)
}

LABURPENA: Biomaterial adimentsuen ikerketan azken urteotan eman den eboluzioak estimuluei erantzuteko gai diren polisakarido naturaletan oinarritutako hidrogelen garapena bultzatu du; izan ere, material horiek bio-bateragarritasuna eta biodegradagarritasuna izateaz gain, giza ehunen birsorkuntzan lagundu dezaketelako. Hidrogel horiek ura xurgatzeko gaitasuna dute eta baita estimulu elektriko, magnetiko, termiko eta kimikoen aurrean erantzuteko gaitasuna; hala, hidrogel polimerikoek zabalik dituzte aplikazio biomedikoetarako ateak.

HITZ GAKOAK: Hidrogel, polisakarido, zelulosa, lignina, kitosano, alginato.

ABSTRACT: The evolution in recent years regarding the development of smart biomaterials that are able to react to external stimuli has created great interest in the field of natural polysaccharide-based hydrogels. These biocompatible and biodegradable hydrogels are not only gifted with high swelling capabilities, but have also been proven to respond to electrical, chemical, thermal and even magnetic stimuli, which enables them to be promising materials for in-situ biomedical applications.

KEYWORDS: Polysaccharide, hydrogel, cellulose, lignin, chitosan, alginate.

\footnotetext{
* Harremanetan jartzeko / Corresponding author: Ainhoa Lejardi. ZIBIO ikertaldea, Meatze eta Metalurgia Ingeniaritza eta Materialen Zientzia Saila eta POLYMAT, Bilboko Ingeniaritza Eskola (48013 Bilbo). - ainhoa.lejardi@ehu.eus - https://orcid. org/0000-0003-4139-4395.

Nola aipatu / How to cite: Mendibe, Mikel; Lejardi, Ainhoa; Sarasua, Jose-Ramon (2021). «Polisakaridoetan oinarritutako hidrogelak eta haien aplikazioak biomedikuntzan»; Ekaia, 39, 2021, 91-112. (https://doi.org/10.1387/ekaia.21871).

Jasoa: 2020, ekainak 30; Onartua: 2020, urriak 5.

ISSN 0214-9001 - eISSN 2444-3255 / (C) 2021 UPV/EHU
}

cc)(1) Obra hau Creative Commons Atribución 4.0 Internacional-en lizentziapean dago 


\section{SARRERA}

Hidrogelak ur kantitate handiak xurgatu eta kontserbatzeko gai diren hiru dimentsioko kate hidrofiliko elkargurutzatuko sare polimerikoak dira. Kimikoki edo fisikoki elkargurutzatutako kate polimerikoek saihesten dute hidrogelaren solubilizazioa uretan, ur kantitate handiak xurgatuz 3D-ko sare polimerikoa hautsi gabe.

Hidrogelen bukaerako propietateak (propietate mekanikoak, biodegradagarritasuna...) prestakuntzara loturiko faktoreen eta kanpo estimuluen menpe daude, eta kitzikapenen aurrean erantzuten duten materialak lortzea ahalbidetzen dute. Hidrogelaren portaeran eragiten duten estimuluak fisikoak zein kimikoak izan daitezke. Alde batetik, estimulu fisikoen artean honakoak ditugu: tenperatura, eremu elektriko eta magnetikoak, presioa eta argia. Bestetik, estimulu kimikoei dagokienez, $\mathrm{pH}$ eta ioi edo konposatu kimiko espezifikoren baten presentzia izan daitezke, besteak beste. Kanpo estimuluen bitartez hidrogelaren propietate mekanikoak aldatu daitezke, eta horrek xurgatutako ur kantitatea kontrolatu. Horrek ahalbidetzen du, hidrogela jada giza gorputzaren barnean egon arren, horren propietateetan eragin ahal izatea kanpo estimuluak erabiliz, eta, hala, biomedikuntzari begira ate ugari zabaldu [1].

Propietate mekanikoen arabera, hidrogelak gel egoeran dauden bitartean material malguak dira, eta ur kantitate handien ondorioz giza ehunen antzeko egitura dute; baina propietate horiek kanpo estimuluen menpe egoten dira betiere. Hidrogelak, urarekin duten harremanari eta giza-ehunen antzeko propietate mekanikoei esker, biobateragarriak izateko potentzial handia daukaten materialak dira [2].

Hidrogelek, bio-medikuntzari begira abantaila ugari eskaintzen dituzten arren, hainbat erronka gainditu behar dituzte material erabilgarriak bihurtu ahal izateko. Alde batetik, horien propietate mekanikoak orokorrean eskasegiak dira karga minimo bat jasan behar duten aplikazioetan erabili ahal izateko. Bestetik, kasu batzuetarako onuragarria izan daitekeen biodegradagarritasuna arazo bihurtu daiteke ehun-ingeniaritzan, hainbat kasutan degradagarritasun goiztiarra gertatu ohi delako. Bukatzeko, hidrogela osatzeko erabili den iturriaren arabera, zailtasunak sor daitezke hidrogel eta giza zelulen artean itsasgarritasuna emateko orduan.

Erronka horiei aurre egiteko ikerkuntzak ari dira egiten hidrogel eta partikula inorganikoz osatutako materialekin, Biobeira (BioGlass) eta kaltzio fosfatoak (hidroxiapatita, kaltzio fosfato bifasikoak...) dira partikula inorganiko horietako batzuk. Nahaste horiek hezurraren osatzea eragiten dute, osteogenesia, alegia, eta hezur zelulen itsaspen eta ugaritzearen bidez ehunaren birsortzean lagundu. Horrez gain, nahaste horiek propietate mekanikoen hobekuntza dakarte, egiturari zurruntasun handiagoa emanez [1]. 
Testuinguru horretan, eta biobateragarritasuna bermatu ahal izateko, polimero naturaletan oinarritutako hidrogelek hartu ohi dute garrantzia; naturan ugariak izateaz gainera, matrize estrazelularrean agertzen diren egituren itxura eta konposaketa daukatelako. Horrek eragiten du giza-gorputzak erraztasunez onartzea polimero natural horiek, bioaktibitate, biobateragarritasun eta biodegradagarritasun handiak ahalbidetuz, bide batez.

Polimero naturalak oso ugariak dira naturan, animalia edo landare iturrikoak, eta hiru multzo nagusitan sailka daitezke: polisakaridoak, polipeptidoak eta polinukleotidoak. Polisakaridoak dira hiru multzo horietatik interesgarrienak hidrogelen garapenerako, elkar-gurutzaketa metodoen bitartez gelifikazio prozedurak aurrera eramateko gai direlako, ur kantitate handiak xurgatu eta estimuluen aurrean erantzuteko gai direlako eta biobateragarriak direlako.

\section{HISTORIA LABURTUA ETA HIDROGELEN SAILKAPENA}

Hidrogel terminoaren lehenengo agerraldia 1894. urtean gertatu arren, gaur egun hidrogel bezala ezagutzen dugun polimero elkargurutzatuetako ikerkuntza XX. mendeko bigarren erdialdean hasi zen, gehienbat aplikazio biomedikoetara bideratuta. Ikerkuntzak aurrera joan ahala, bai helburu eta bai erabilitako materialak asko aldatu dira. Hidrogelen historia hiru aro nagusitan sailkatu daiteke, bakoitzean bilatutako helburuen arabera [2].

Hidrogelen lehenengo belaunaldian, elkargurutzaketa kimiko zein fisikoen bitartez ur kantitate handia gorde eta propietate mekaniko onargarriak zituen material bat bilatzera zegoen bideratuta ikerketa. Ondoren, 70eko hamarkadatik aurrera, aurrerapauso handiak eman ziren kanpo kitzikapenen aurrean $(\mathrm{pH}$ aldaketak, tenperatura aldaketak...) erantzuna eman zezaketen hidrogelen ikerkuntzan. Hidrogel horiek ehun-ingeniaritza eta farmakoen horniketa-sistemetara daude zuzenduak, norbanakoen bizi-kalitatea hobetzeko prozedura ez inbaditzaileen baitan. Azkenik, hirugarren belaunaldian, material estero-konplexuen sorkuntzara bideratu da ikerkuntza. Esterokonplexuak konposizio kimiko berdina baina konfigurazio desberdina duten unitatez osatutako makromolekulak dira [3].

Hidrogelak hainbat modutara sailkatu daitezke hautatutako irizpidearen arabera, eta honako irizpideen araberako sailkapenak daude onarturik [4]: (i) prestakuntza prozesua; (ii) karga ionikoa; (iii) elkar-gurutzaketa metodoa; (iv) estimuluen aurreko erantzuna; (v) propietate fisikoak; (vi) iturria. 


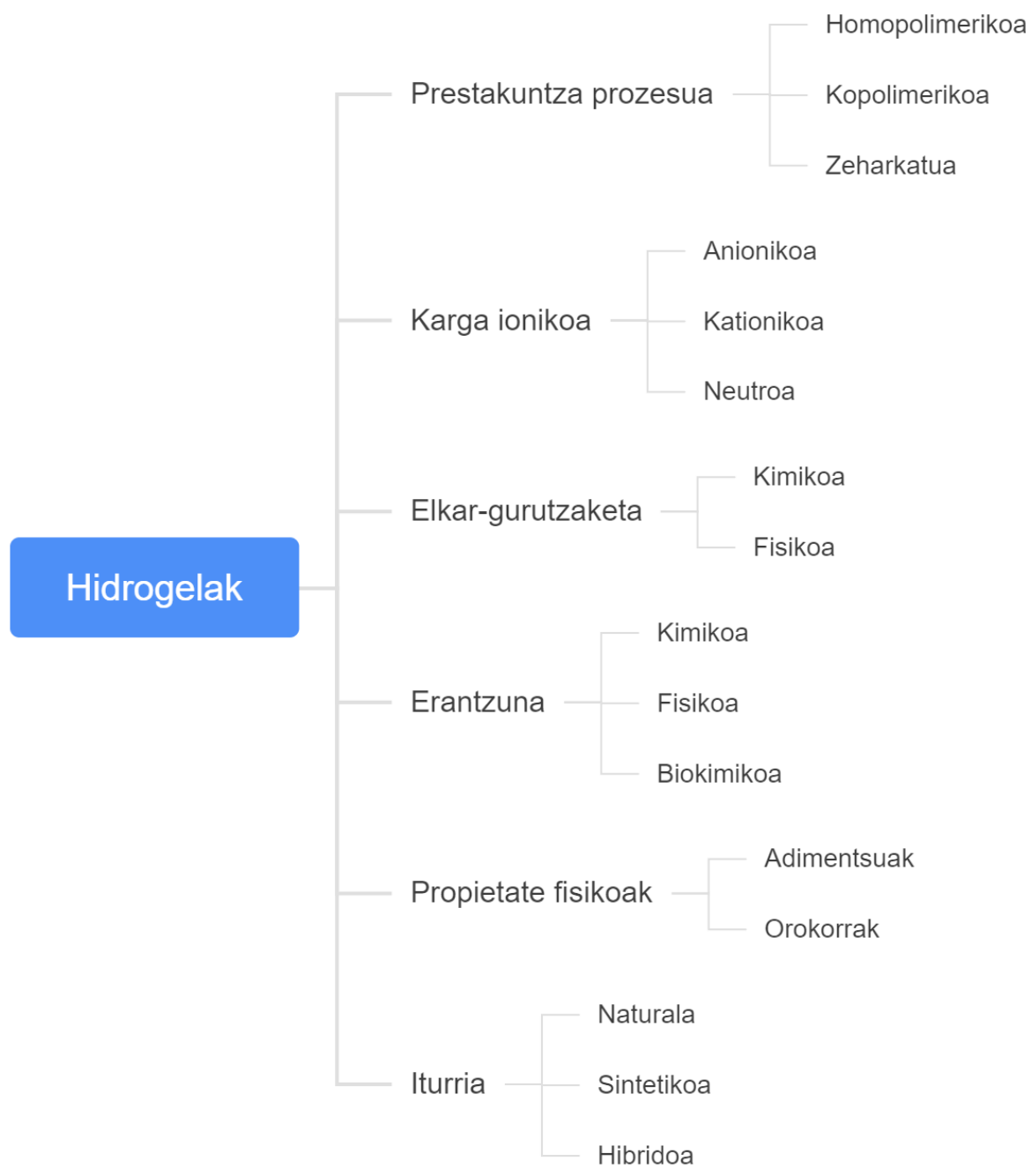

1. irudia. Hidrogelen askotariko sailkapenak.

\subsection{Iturriaren araberako sailkapena}

Iturriaren arabera eginez azterketa, hidrogelak hiru multzo nagusitan sailkatu daitezke: naturalak, sintetikoak eta hibridoak.

Hidrogel naturalei dagokienez, horien abantaila nagusia biobateragarritasun maila handia da, giza gorputzarekin maila zelularrean atxikitzeko erraztasuna ematen diena. Hala ere, iturri naturaletatik lortzen direnez osagaiak, errepikakortasun arazoak daude, lortutako produktuen artean emaitza ezberdinak lortzen baitira haien sasoiko ezaugarrien arabera. 
Hidrogel sintetikoak erreprodukzio erraz eta fidagarria bermatzen duten materialak dira, propietate kimiko eta fisikoen doikuntza ahalbidetzen dutenak. Hala ere, oro har biobateragarritasun maila txikiagoa da naturaletan baino, eta biodegradagarriak izan ohi ez direnez, gorputzean hondakin kaltegarriak uzteko arriskua ager daiteke.

Hidrogel hibridoen kasuan, ordea, bi muturren arteko hidrogelak lortzea izan ohi da helburua, hidrogel naturalen biobateragarritasuna eta sintetikoen errepikakortasuna bilatuz. Horretarako sorburu naturala duten polimeroak kimikoki eraldatzen dira, haien propietate fisiko eta kimikoak nahieran aldatuz eta biobateragarritasuna mantenduz.

Azken hamarkadetan hidrogel naturalen arloan aurrerapauso garrantzitsuak eman dira biobateragarritasuna eta propietateen errepikakortasuna bermatzeko helburuarekin, gehienbat polisakaridoen inguruan, eta haiek izan dira aplikazio berritzaileen sorburua [4].

\section{POLISAKARIDOAK}

Polisakaridoak zer diren aztertzeko biderik garbiena horien etimologian oinarritzen dena da, grezieratik eratorritako hitz hori hiru osagai nagusiz osatuta baitago. Alde batetik «poly» aurrizkia, «asko»ren sinonimo dena; bestetik «sakkhar» izena, «azukre» bezala itzuli daitekeena; eta bukatzeko «ido» atzizkia [5].

Polisakaridoak lotura glikosidikoz lotutako monosakaridoz osaturiko pisu molekular handiko polimero naturalak dira. Monosakaridoaren konposizioak, lotura motak edo katearen formak eragin zuzena daukate polisakaridoaren propietate fisikoetan, hala nola disolbagarritasunean, biskositatean edo gelifikatzeko potentzialean.

Polimero horiek ugariak dira naturan, landare, animalia zein mikroorganismoen artean; beraz, iturri berriztagarri bat direla ondoriozta daiteke. Degradazio metabolikora bideratuta egotea da polisakaridoen bereizgarria, eta horrek biomaterial interesgarriak osatzeko baliogarriak bihurtzen ditu. Iturri biologikoa izateak propietate fisiko eta kimiko paregabeak ematen dizkien arren, askotan mugatu egiten du haien erabilgarritasuna, polimero sintetikoekin alderatuta [6]. Polisakarido gehienak uretan disolbagarriak dira, eta horrek hasiera batean, asko mugatzen du haien erabilera. Zailtasun horri aurre egiteko elkar-gurutzaketa bermatzen duten teknikak garatu dira, polisakaridoen egitura egonkortu eta uretan egituraren osotasuna lortzeko eta, hala, aplikazio biomedikoetarako ateak zabaltzeko [7].

Polisakaridoen artean, aplikazio biomedikoetarako hidrogelen sorkuntzara bideratutako etorkizun handiko materialak honakoak dira: kitosanoa, alginatoa, zelulosa, almidoia eta karragenanoa. 


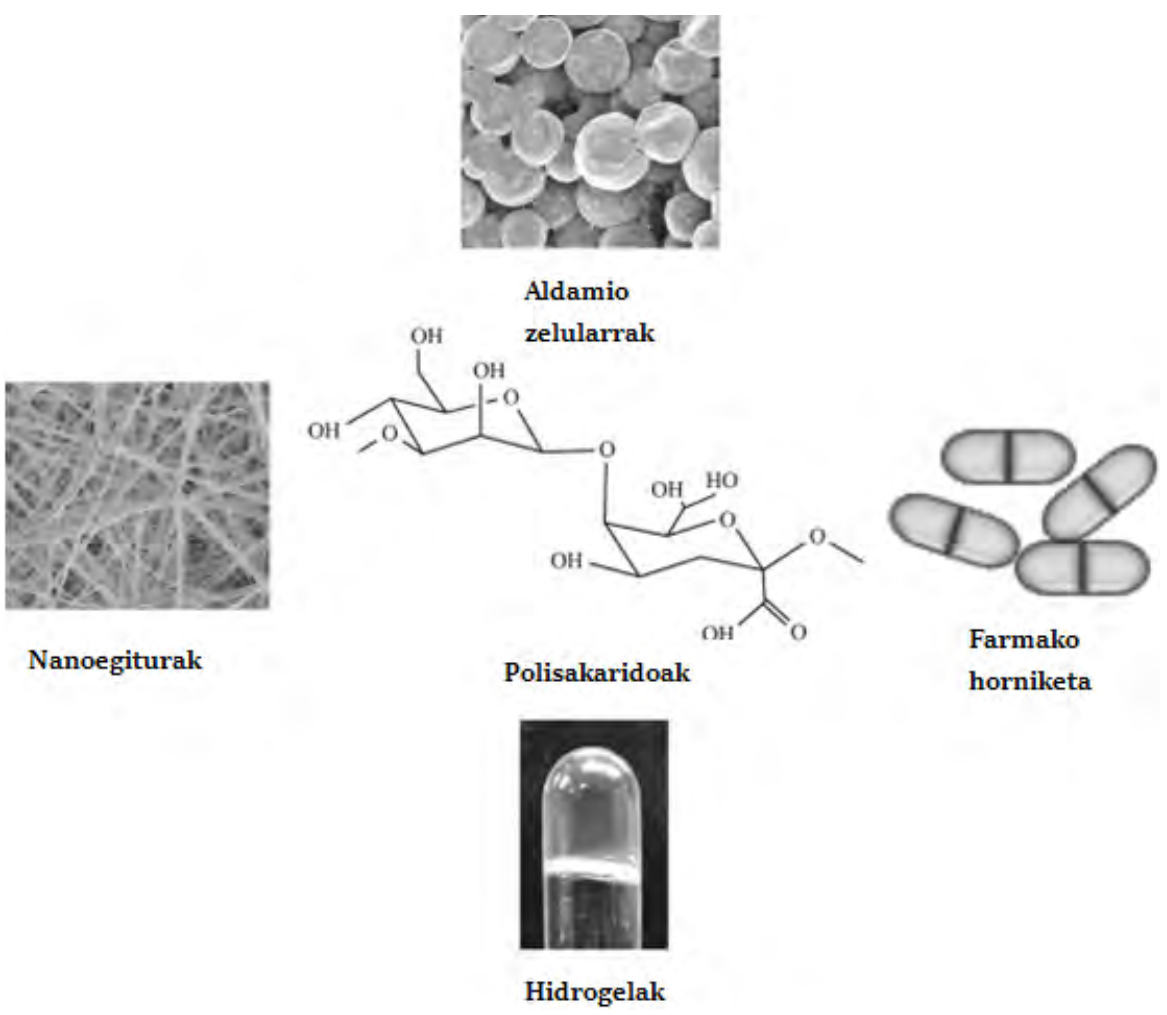

2. irudia. Polisakaridoen aplikazioak biomedikuntzan.

\subsection{Kitosanoa}

Kitina naturan ugaria den mukopolisakaridoa da, krustazeoen exo-hezurdura, intsektu eta onddoen pareta zelularrean ageri dena; lurreko polisakarido ugarienetarikoa da zelulosaren atzetik.

Kitinaren deribatu garrantzitsuenetarikoa kitosanoa da, eta kitinaren desazetilazio alkalino partzialaren bitartez lortu ohi da. Oinarrizko egoeran kitosanoa uretan disolbatzen ez den arren, $\mathrm{pH}$ azidoetan disolbatu daiteke, amino taldeak ionizatu egiten direlako chit- $\mathrm{NH}_{3}{ }^{+}$konposatua osatuz eta solubilitatea areagotuz [61]. Kitosanoak hidrogela osatzeko duen gaitasuna hidrogeno zubiak sortzeko ahalmenaren ondorioz gauzatzen da, $\mathrm{pH}$-arekiko mendekotasun zuzena izanik [8]. 


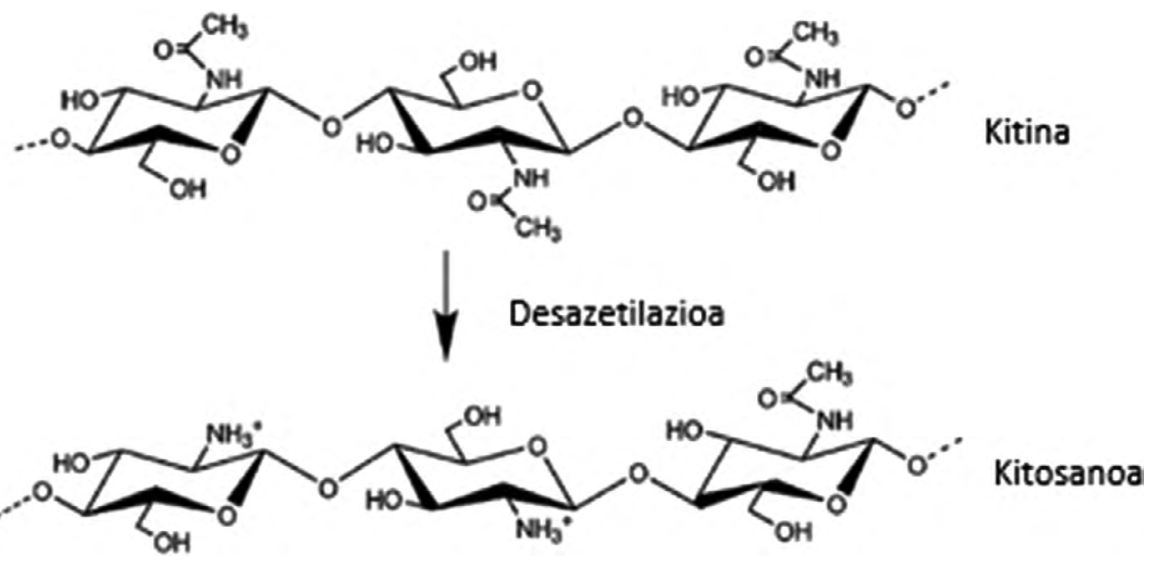

3. irudia. Kitinaren desazetilazioa [62].

\subsubsection{Aplikazioak}

Masa molekularra eta desazetilazio gradua dira kitosanoaren bi propietate nagusiak; izan ere, farmako-horniketarako matrize molekular lana burutzeko orduan eragin zuzena dute. Propietate horiek hidrogelaren disolbagarritasun eta hidrofobizitatea kontrolatzen dituzte, eta farmakoaren enkapsulazioaren efizientzia zehazten.

Horrekin batera, kitosanoak gorputzera moldatzeko orduan erabilgarriak diren propietate muku-itsaskor, porotsu eta biodegradagarriak erakusten ditu eta, ondorioz, lagungarriak dira material biobateragarri batentzat.

Aitzitik, kitosanoaren erabileran desabantaila nagusia disolbagarritasuna da, gorputzeko azidoekin kontaktu zuzenak hidrogela arinegi degradatzea eragin dezakeelako; elkar gurutzaketa metodoen bitartez horren eragina murriztea lortu den arren.

Horrek guztiak, biobateragarritasun, biodegradagarritasun eta kanpo estimuluei sentikorrak diren kitosanoan oinarritutako hidrogelekin, Farmako Horniketara Bideratutako Sistemen (Drug Delivery Systems, DDS) eta ehun ingeniaritzaren garapena bultzatu du [11].

\subsubsection{Farmako Horniketara Bideratutako Sistemetan}

Farmako Horniketara Bideratutako Sistemena puri-purian dagoen arloa da, botika gure gorputzean modu kontrolatuago eta konstanteagoan hornitzea ahalbidetzen duelako, piluletan oinarritutako metodo tradizionaletan ez bezala. Azken horrek farmakoaren kontzentrazioan ez-jarraitasunak eragiten ditu; maila konstantea mantendu nahi izanez gero, pilula bakoitza- 
ren farmako kontzentrazioa murriztu eta kontsumo maiztasuna areagotzera behartuko luke. Hori, deserosoa izateaz gain, arriskutsua ere bada, batik bat adineko pertsonentzat zaila izan daitekeelako aurreikusitako pilulen plangintza jarraitzea.

Hidrogeletan oinarritutako DDS-ak ahalbidetu dezake farmakoa maiztasun gutxiagorekin kontsumitu behar izatea, eta horren kontzentrazioa gorputzean konstante mantentzea denbora aurrera joan ahala.

Kitosanoan oinarritutako DDS-ak bereziki interesgarriak dira horren biodegradagarritasuna, lotura epitelial estuak irekitzeko gaitasuna eta propietate mukoitsaskorrak direla eta. Mukoitsasgarritasuna kitosano eta mukosaren artean ematen diren elkarrekintza elektrostatiko, efektu hidrofobiko eta hidrogenozko zubien ondorio da [12]. Biodegradagarritasuna, ordea, kitosanoa gorputzak naturalki sortzen dituen lisozima (lysozyme) eta kitinaso (chitinase) entzimetan disolbagarria delako gertatzen da. Hori guztia dela medio, kitosanoan oinarritutako DDS-ak erabilgarriak dira gorputzeko hainbat epiteliatan zehar (begikoa, sudurrekoa, ahokoa...) farmakoaren askapen kontrolatua lortzeko.

Kitosanoan oinarritutako hidrogelak elkar-gurutzaketa prozesu fisiko zein kimikoen bitartez lor daitezke; eta, horrez gain, horien talde funtzionalek beste monomero sintetiko batzuekin hibridatzea ahalbidetzen dute, propietate mekanikoak hobetzeko edo uraren xurgatzea areagotzeko helburuarekin. Hainbat polimero sintetikorekin burutu dira hibridazio horiek (PVA, poliakrilamida...), propietate mekaniko sendoagoak lortzeko helburuz $[13,14]$. Polisiloxano hiperadarkatutako egitura molekularrak garatu dira, eta, hala, poliakrilamida eta kitosanoan oinarritutako hidrogeletan elkar-gurutzaketa ahalbidetu eta propietate mekaniko gorenak dituzten hidrogelak lortu. Horrez gain, prozedura horren bitartez lortutako hidrogelek kitosanoan soilik oinarritutakoek baino erresistentzia handiagoa erakutsi zuten konpresio-ziklikoen saiakuntzan, oso interesgarria izan daitekeena materiala gorputzeko alde zigortu batean aplikatu nahi bada [15].

\subsubsection{Ehun-ingeniaritzan}

Ehun-ingeniaritzaren arloan, giza gorputzera moldatu eta horrekin bat egin dezaketen materialak lortzea da gaur egungo biomedikuntzaren erronka garrantzitsuenetarikoa.

Kitosanoan oinarritutako hidrogelak oso erabiliak izan dira hezurren ehun-ingeniaritzan, osteogenesia ahalbidetzen duten matrize zelular porotsu, biodegradagarri, biobateragarri eta egonkorrak eratzen dituztelako. Horrez gain, hezurraren osagai nagusi den hidroxiapatita partikula inorganikoekin nahastutako kitosanoan oinarritutako hidrogelak garatu dira, eta hidroxiapatitaren osteoeramangarritasun (osteoconductivity) eta bioakti- 
bitateaz baliatu eta hezurren ehun-ingeniaritzara bideratutako matrize zelular baliagarriagoak lortu [16, 17]. Huang et al.-ek kitosano eta azido hialuronikoan oinarrituta garatutako hidrogelean, porositatea azido hialuroniko kontzentrazioarekin areagotzea lortu zuten, eta, hala, osteogenesia bultzatu eta toxikotasunik gabeko egitura zitobateragarriak (cytocompatible) lortu [17].

Kartilagoen ehun-ingeniaritzarian, kitosanoak glikosaminoglikanoen (glycoaminoglycan) antzeko ezaugarriak izan eta horren propietate funtzionalak imitatu ahal dituenez, kartilago-ehunen garapena bideratzeko matrize zelular lanetan erabil daiteke [18]. Hong et al.-ek kolagenoz inguratutako poliaktida mikroeramaile eta kitosanoan oinarritutako hidrogela garatu zuten, ehunen hazkuntza bultzatzeaz gain propietate mekaniko sendoagoak zituena [19].

\subsection{Alginatoa}

Alginatoa edo azido alginikoa, egitura linealeko heteropolisakarido mota bat da, alga marroietatik lor daitekeena (Laminaria sp., Macrocystis sp., etab.). Hainbat bakterio ere alginatoa sintetizatzeko gai diren arren, gaur egun alginatoa lortzeko iturri nagusia itsas belarrak dira. Horrek eragiten du kalitatea urtaroek eragiten dituzten bariazioen menpe egotea eta prozesuan ezjakintasun puntu bat sartzea.

Alginatoen propietate garrantzitsuena kateetako karboxil taldeen ondorioz katioi dibalenteen presentziarekin ematen den gelifikazioa da, azido karboxilikoz osatutako taldeak katioi dibalenteekin elkargurutzatzen baitira gel bat eratu ahal izateko, «arrautza-kutxa» deituriko egitura osatuz. Gelaren propietateetan eragin zuzena dauka bai alginato kontzentrazioak, bai masa-banaketak [20].

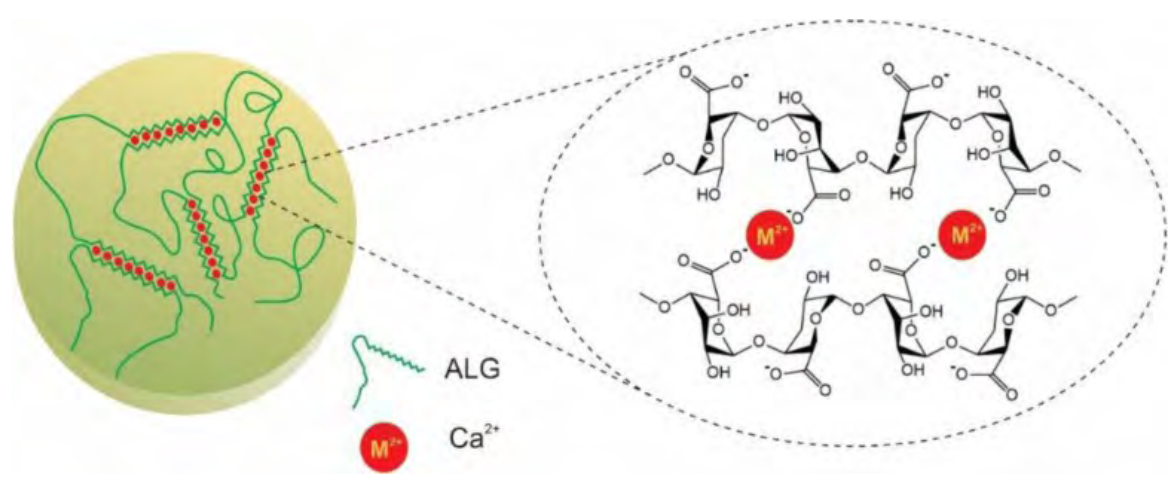

4. irudia. Alginatoaren gelifikazioa $\mathrm{Ca}^{2+}$-ren presentzian, «arrautza-kutxa» egitura [63]. 


\subsubsection{Aplikazioak}

Ehun-ingeniaritza eta DDS aplikazioetan alginatoaren baliagarritasuna aztertzeko, horren biodegradagarritasuna aztertu behar da. Kasu horretan, depolimerizazio oxidatibo-erreduktiboa gertatzen da, ez, ordea, degradazio entzimatikoa (alginatoaren izaera inertea dela eta), eta horrek muga garrantzitsuak ezartzen ditu.

Muga horiek gainditu ahal izateko alginatoa beste polimero batzuekin nahasten da haien degradatzeko portaera eta izaera mekanikoa lortzeko asmoz. Polietilinamina (Poly(ethyleneimine)) kationikoa (PEI) da hibridazio prozesu horretako konposatuetako bat, gelaren propietate mekanikoak hobetzen laguntzen duelako, gehienbat ehun-ingeniaritza aplikazioei begira. Arlo horretan, gelen propietate fisiko, kimiko eta biologikoak eraldatu egiten dira desiragarriagoak izan daitezen, hala nola oxidazio, sulfatazio edo kopolimerizazioaren bitartez [20].

\subsubsection{Farmako Horniketara Bideratutako Sistemetan}

Farmako Hornikuntza Sistemetan alginatoan oinarritutako hidrogelak erabili izan dira masa molekular txikiko konposatuak garraiatu ahal izateko, non botikaren askapen ratioa molekulen polaritatearen arabera kontrolatu daitekeen (molekula hidrofilikoak azkar askatuko dira; hidrofobikoak, ordea, motelago). Bereziki interesgarria da kontzeptu hori minbiziaren tratamendu den kimioterapiaren kasuan, zeinean, prozedura ez selektiboa denez, toxizitate sistematikoa eragiten duen gaixoaren gorputzean, eta albo-ondorio kaltegarriak sorrarazten. Ingurunearen $\mathrm{pH}$-aren arabera alginatoak bi motatako hidrogelak osa ditzake; ingurune azido batean dagoela (hala nola digestio sistema) txikitu eta trinkotu egiten da, eta askapena eragozten; ingurune basikoetan ordea, sare polimerikoaren haustura partziala gertatzen da, eta botikaren disoluzio eta askapena ahalbidetzen. Fenn et al.-ek bikoizki elkargurutzatutako metakrilato-alginato sub-mikroesferak garatu zituzten biriketako minbizirako botiken garraiatzaile bezala. DOX erabili zen botika-modelo bezala, eta, alginatoan oinarritutako hidrogela erabiliz, askapen kontrolatu eta eraginkorra lortu zen [21].

\subsubsection{Zaurien apositu bezala}

Erredura eta zauri larriak sendatzeko aposituak aspalditik erabili izan diren arren, alde txar garrantzitsu bat zeukaten: gorputzetik kentzean beraiekin eramaten zutela giza azala. Horri aurre egiteko, hidrogeletan oinarritutako aposituak garatu dira, infekzioa eten, odoljarioa moztu eta zauriarentzat sendatze ingurune aproposa osatzeko. Biobateragarritasun, porositate, ur kantitate handiak eusteko gaitasun eta likido eta gasekiko ira- 
gazgaiztasunari esker, alginatoan oinarritutako hidrogelak zaurien apositu bezala lan egiteko material aproposak izango ziratekeen, baina propietate mekaniko ahulak oztopo garrantzitsu bat dira [22, 23]. Arazo horri aurre egiteko alginatoa beste polimero sintetiko edo natural batzuekin nahasten da, abantailak mantendu eta propietate mekaniko sendoagoak lortzeko helburuz. Saarai et al.-ek alginato eta gelanitan oinarritutako hidrogela garatu zuten, zaurien sendatzea bizkortzeaz gain giza azalaren propietate biskoelastiko antzekoak zituena [24].

\subsubsection{Bioimprimaketa 3D-n}

Giza organoen transplanteak milioika bizitza salbatu dituen arren, muga larriak dituen prozedura da. Alde batetik, emaileen kantitate mugatua; eta, bestetik, gorputzaren erantzun immunologiko bortitza transplantatutako organoen aurka. Irtenbide bezala, 3D-ko bioinprimaketa jaio zen, biozuntz baten bitartez, matrize finko gabeko egiturak inprimatzea ahalbidetzen duena, benetako ehunen egitura imitatuz. Hidrogelak biozuntz hori garatzeko material interesgarri bat dira, soluzio eta gelifikazio arteko tartean mantenduz, inprimatzeko behar den biskositateari euts dakiokeelako, eta, hala, giza ehunen antzekoak diren materialak inprimatu eta haien gainean zelulen hazkundea ahalbidetu.

Sodio alginatoa da biozuntz horietako baten oinarria, biobateragarritasun handiari esker zelulen hazkunde bizkorra bultzatzen baitu. Hala ere, propietate mekaniko kaxkarrak direla eta (gehienbat kaltzio katioien presentziarekin gelifikatu denean), inprimatutako materialaren egituraren osotasuna ezin da bermatu, eta arazoak izaten ditu orokorrean grabitatearen eraginari aurre egiteko $[25,26]$. Hori horrela izanik, alginatoa beste polimero batzuekin nahasten da, hidrogel sendo eta fidagarriagoak lortzeko; hala nola kitosanoa [27].

\subsection{Zelulosa}

Zelulosa elkarri lotutako ehunka $D$-glukosa unitatez osatuta dagoen kate-linealeko egitura duen polimero naturala da. Oso polimero ugaria da naturan, kotoian edo lihoan aurkitu daitekeelako; horrez gain, kitina edo kitosanoaren bitartez ere lor daiteke zenbait propietaterekin.

Zelulosa naturalean oinarritutako hidrogelak presta daitezke zelulosa puruko disoluzio batetik abiatuta, hidroxil taldeen oparotasunak hidrogeno zubien garapena ahalbidetzen duelako, sare polimerikoa osatuz. Lortutako hidrogelaren propietate fisiko eta kimikoak sare polimerikoaren egitura supramolekularraren menpe daude.

Zelulosa puruan oinarritutako hidrogelek hainbat gabezia garrantzitsu uzten dituzte agerian; hala nola disolbagarritasun kaxkarra ohiko disolba- 
tzaileetan, egonkortasun dimentsional eta propietate mekaniko ahulak, termoplastizitate eza, portaera oso hidrofilikoa eta mikrobioen aurkako erresistentzia falta.

Zelulosa puruan oinarritutako hidrogelak lortzeko aukera dagoen arren, hidrogeno zubien ugaritasuna dela eta, ez da oso material prozesagarria. Horren ondorioz, zelulosa gehienbat bere deribatuen bitartez edo beste polimero natural edo sintetikoekin nahastuta erabiltzen da (alginatoa, kitosanoa, PVA...), eta prozesatzeko errazagoak diren hidrogel hibridoak lortu.

Alde batetik, zelulosaren deribatuen artean interesgarrienak zelulosa ester eta eterrak dira, hidroxil talde aktiboak beste konposatu organiko batzuekin (metil eta etil taldeak) erreakzionatzean ematen direnak [20]. Zelulosa esterrek disolbagarritasun eta propietate termiko interesgarriak erakusten dituzte, eta bioaktibitate maila altuak mantentzen. Eterrak, ordea, zelulosaren alde ez-kristalinoak aktibatuz lortzen direnak, interesgarriagoak dira horien propietate mekanikoak sendoagoak direlako.

Bestetik, zelulosan oinarritutako hidrogel hibridoen ikerkuntzan hazkunde handia gertatu da azken hamarkadan, aplikazio elektriko, optiko, magnetiko eta biologiko berritzaileetarako ateak zabal ditzaketelako [14]. Zelulosaz gain, sodio alginato, silizio, PVA edo poliakrilamidaz osatu ohi dira hidrogel hibridoak, eta propietate mekaniko sendo eta egonkorrak lortu [28].

\subsubsection{Aplikazioak}

Zelulosan oinarritutako hidrogelak oso material interesgarriak dira hiru arrazoi nagusiri esker; (i) iturri naturaletatik eratorrita dagoen heinean, horren propietate intrintsekoak dira biobateragarritasun, biodegradagarritasun, eta toxikotasun eza; (ii) zelulosaren egituran dauden hidrogeno-zubi intramolekular eta intermolekularrei esker, propietate mekaniko bikainak ditu (nahiz eta zelulosan soilik oinarritutako hidrogelak ahulak izan); (iii) zelulosa estimuluekiko sentikorrak diren polimeroekin elkargurutzatuz gero, zelulosan oinarritutako eta estimuluei sentikorrak diren hidrogelak lor daitezke $[29,30]$.

Biomedikuntzaren arloan, kitosano eta alginatoaren kasuetan bezala, hornikuntza kontrolatuko sistema eta ehun-ingeniaritzaren esparruetan dira erabilienak zelulosan oinarritutako hidrogelak, giza ehunaren antzekoak diren egiturak osatzen dituelako [31]. Horrez gain, haien sentikortasunaz baliatuz, hainbat konposatu kimikoren presentzia detektatzeko gai diren biosentsoreak garatu dira. 


\subsubsection{Farmako Horniketara Bideratutako Sistemetan}

Kautxuaren antzeko propietate mekanikoak izan eta ur kantitate handiak xurgatzen dituzten hidrogel biobateragarriak material bikainak dira molekula bioaktiboak garraiatzeko. Hidrogelaren porositate eta ur kantitatea, prestakuntza prozesuaren menpe egoteaz gain, inguruneko estimuluen menpe daude ( $\mathrm{pH}$, tenperatura...); estimulu horiekiko sentikorrak diren materialak lortuz. Besteak beste, zelulosa/ $\mathrm{Fe}_{2} \mathrm{O}_{3}$ nahastean oinarritutako hidrogelak garatu dira, eremu magnetikoen bitartez proteinen askapen kontrolatua bideratzen dutenak [32].

\subsubsection{Ehun-ingeniaritzan}

Ehun-ingeniaritzaren alorrean, zelulosan oinarritutako matrizeak erabili izan dira zelulen hazkuntza bideratu eta ehun berriak osatzeko [33]. Hiru dimentsioko matrize porotsu bat eraikitzen da, barnean zelula biziak dituena, biopolimeroaren bitartez zelula horien hazkuntza sustatuz, ehun funtzional bat lortu arte. Zelulosan oinarritutako matrizeek ingurune bikaina osatzen dute espazio eta mantenugaien ikuspegitik hezurren, muskuluen, azalaren zein tendoien ehunak eraiki ahal izateko, besteak beste $[34,35]$. Horrez gain, zelulosan oinarritutako hidrogelak erabili izan dira inplante sintetikoek gorputzarekiko duten biobateragarritasuna bermatzeko, gainazala material horrekin babestuz eta zelulen itsaspena bermatuz [36].

\subsection{Almidoia}

Almidoia glukosan oinarritutako polisakarido naturala da, patata, arto, arroz eta tapiokatik eratorritakoa, batik bat. Egitura erdi-kristalinoa dauka naturan, eta glukosaren bi deribatuz dago osatua, amilosaz eta amilopektinaz. Amilosa kate linealetan agertzen da gehienbat; bestalde, amilopektina dentsitate handian adarkatutako egituratan agertzen da; osagai horien proportzio eta ordenamenduak almidoiaren bukaerako propietateetan eragin zuzena dute.

Almidoia ur soberakinarekin kontaktuan dagoela berotzen bada, gelifikazioa gertatuko da, non hidrogeno zubien hausturak egitura erdi-kristalinoa apurtuko duen, eta ur kantitate handiak xurgatzen dituen sare polimerikoa osatuko den. Gelifikazio maila kontrolatu daiteke, eta, hala, egitura kristalinoa guztiz ez desegin eta entzimen aurrean erresistenteagoa eta mekanikoki zurrunagoa den materiala lortu [37].

Almidoia konposatu guztiz degradagarria da, eta horren adibide da gizakion eguneroko elikaduraren oinarrietako bat izatea. Kasu horretan biodegradazioa listu eta guruin pankreatikoan dauden entzimen bitartez egiten da, digestio prozesuaren barnean. Arrazoi horiek direla medio, interesgarria 
da almidoi erresistente bat sortzea, entzimen eraginaren aurrean egitura eta propietate mekanikoak mantentzeko gai dena.

\subsubsection{Aplikazioak}

Almidoiaren aplikazioak aztertzeko orduan, aipatu behar da, aurrez aipatutako degradazio entzimatikoa dela eta, almidoi puruan oinarritutako hidrogelak ez direla orokorrean erabiltzen, horretan oinarritutako deribatuak baizik. Deribatuak lortzeko modifikazio kimiko, fisiko eta entzimatikoetan oinarritutako metodoak erabiltzen dira, degradazioaren aurrean egonkorragoa eta sendoagoa den hidrogela lortzeko [38, 39].

Almidoian oinarritutako hidrogelen aplikazioak, aurreko kasuetan bezala, biomedikuntzan zehar hedatzen dira; zaurientzako apositu, DDS eta ehun-ingeniaritzaren alorretan [40].

\subsubsection{Farmako Horniketara Bideratutako Sistemetan}

Aplikazio biomedikoetarako proteina eta peptidoen erabileraren hazkuntzak bultzatu du horien horniketa kontrolatu eta eraginkorra bermatzen duten askapen metodoen garapena; hidrogel biobateragarri eta biodegradagarriak dira adibide garbia. Harling et al.-ek argiaren eraginez elkar-gurutzatzen zen almidoi hidroxietil deribatuan oinarritutako hidrogela garatu zuten, eta horren egitura porotsuari esker farmakoa garraia zezaketen mikro-partikulak osatu. Farmakoaren horniketa aztertzean, hasierako askapen handi baten ondoren lau hilabeteren buruko askapen kontrolatua neurtu zen; eta epe luzerako farmakoen horniketarako baliabide erabilgarria dela erakutsi [41]. Horrez gain, eta askapen selektiboagoa lortzeko helburuarekin, Sadeghi-k azido akriliko, metakrilato eta almidoian oinarritutako hidrogela garatu zuen, $\mathrm{pH}$-arekiko oso sentikorra zena, eta askapen ratio desberdinak zituena $\mathrm{pH}$-aren arabera. Oso propietate interesgarria da hori, farmakoaren aplikazio eraginkorragoa ahalbidetu dezakeelako hainbat kasutan, hanturaren aurkako farmakoen kasuan, adibidez [42].

\subsubsection{Ehun ingeniaritzan}

Propietate mekaniko ahulak direla eta, almidoian oinarritutako hidrogelak ez dira gehiegi erabili ehun-ingeniaritzaren arloan; eta, erabili direnean, beste polimero batzuekin nahastuta izan da, gehienbat kitosanoarekin. Viyoch et al.-ek kartilagoen ehun-ingeniaritzara bideratutako hidrogel termosentikorra garatu zuten kitosano eta almidoiaren nahastean oinarrituta; almidoiaren presentziak poroen batez besteko tamaina handitu ahal zuelako eta, aldi berean, propietate mekanikoak mantendu eta egitura baliagarriagoa osatu $[43,44]$. 


\subsubsection{Garunerako elektrodoen eraketan}

Historikoki platino, urre eta beste hainbat metaletan oinarritutako elektrodoak erabili dira interfaze neuronaletan; hala ere, gaur egun gailu txikiagoak behar dira, propietate mekaniko, elektriko eta biologiko gorenekin. Ildo horretatik, almidoi eta grafenoan oinarritutako hidrogelak garuneko inplanteetarako elektrodoak garatzeko ere erabili dira, modifikazio fisiko eta kimikoen bitartez eroankortasun handia duten material sendo eta zurrunak lortu baitira, mikrobioen eta hanturaren aurkako propietateak dituztenak [45].

\subsection{Karragenanoa}

Karragenanoak Rhodopycea familiako Chondrus, Euchema, Gigartina eta Hypnea alga gorri klaseetatik eratorritako galaktano sulfatatuak dira. Galaktopiranosa (galactopyranose) familia ezberdinez osatutako unitate errepikakorreko pisu molekular handiko kateentzako izen orokorra da karragenanoa, horren barnean sulfatazio mailaren araberako hainbat familia egonik. Propietateei dagokienez, karrageno familia guztiak dira disolbagarriak uretan, eta disolbaezinak disolbatzaile organikoetan; eta disolbagarritasuna sulfato taldeen mailaren araberakoa da. Karragenoen biskositatea hainbat faktoreren menpe dagoen arren (tenperatura, karragenano mota, pisu molekularra...), biskositatearen hazkuntza bi fenomeno nagusiren bitartez ematen da: (i) kate linealen arteko elkarrekintza, hutsuneak murriztuz; (ii) kateen elkargurutzaketaren ondorio den gelifikazioa. Bigarren fenomeno horrek karragenanoetan oinarritutako hidrogelen sorkuntza ahalbidetzen du [46].

Orokorrean, propietate mekaniko ahulak dituzten arren ingurune fisiologikoetan, sare polimeriko nagusiaren modifikazio kimikoak garatu dira propietate mekaniko sendoagoak lortzeko [46], hala nola oxidazioa [47], gain-sulfatazioa [48], metakrilazioa [49]...

\subsubsection{Aplikazioak}

Gelifikazio termo-itzulgarri, biobateragarritasun, gelifikazio prozesu sinpleak eta kontrolatu daitezkeen propietate biskoelastikoak direla eta, karragenanoan oinarritutako hidrogelak oso material interesgarriak dira biomedikuntzara begira. Hala ere, toxikotasunaren azterketen arabera, ikusi da karragenanoa toxikoa eta oso inflamatorioa dela digestio hodiarentzat, eta horrek hidrogel horien aplikazioa mugatzen du.

\subsubsection{Farmako Horniketara Bideratutako Sistemetan}

Karragenanoaren propietate fisiko-kimikoak direla eta (pisu molekular handia, biskositate handia...), epe-luzeko horniketa bermatzen duten ahoz 
irentsitako farmakoak garatzeko erabiltzen da [50]. Hala ere, karragenanoa horniketa kontrolatua bideratzeko matrize material bakarra denean, zaila izan daiteke zero-mailako horniketa lortzea, edo $\mathrm{pH}$-arekiko independentea izatea askapena. Hori horrela izanik, polimero nahasketak erabiltzen dira horniketa kontrolatuagoa lortzeko [51]; hala nola zelulosa eterrak, guar goma... Rasool et al.-ek PVA eta kappa-karragenanoan oinarritutako hidrogela garatu zuten, Cephradine farmakoaren askapena aztertzeko. Emaitzek 8 orduren inguruko zero mailako askapena erakusten dute, eta denbora horren bitartean askapen kontrolatua lortu zen, pilulekin ematen den hasiera bateko horniketa maximoa saihestuz [52].

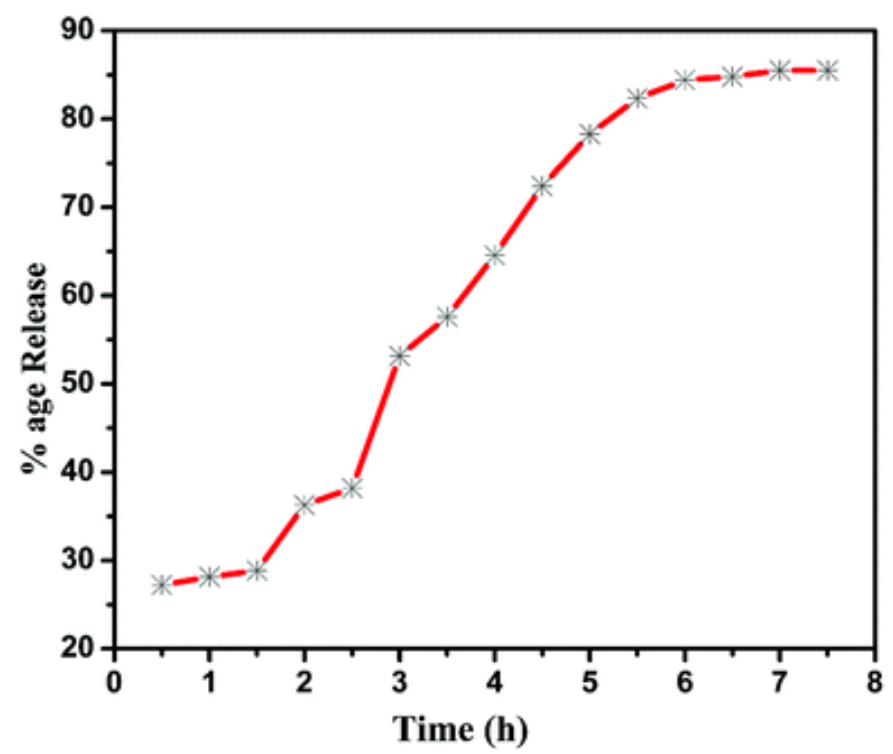

5. irudia. Cephradine farmakoaren horniketa kontrolatua [52].

Horrez gain, farmako hornikuntzarako mikrokapsula zein mikroesferak eratzeko ere erabiltzen dira karragenoan oinarritutako hidrogelak [53, 54].

\subsubsection{Ehun-ingeniaritzan}

Hezurren ehun ingeniaritzan, ehunen hazkuntza berma dezakeen matrize baten sorkuntza da gaur egun erronka handiena. Karragenanoan oinarritutako hidrogelak oso material interesgarriak dira eremu horretan, apatita geruzen sorkuntza ahalbidetzen duelako, eta bioaktibitatea bermatu [55]. Horrez gain, ikusi da kolageno-hidroxiapatita gelean karragenanoa gehituz gero, horren propietate mekanikoak hobetu egiten direla, gehienbat konpresio saiakuntzaren aurrean [56]. 
Karragenanoaren egituran dauden sulfato taldeei esker, kartilagoaren zelulen matrizearen kanpoaldean ageri diren glikosaminoglikanoen antzeko portaera daukate, eta horrek kartilagoen ehun ingeniaritzarako ateak zabaltzen ditu [57]. Ionikoki elkargurutzatutako karragenanoaren disoluzio-ratio bizkorrari esker, konposatu toxikoen pilaketa ekidin ahal izan zen, eta hantura murriztu [58]. Giza zelula adiposoak hidrogelean sartuz gero, kartilago ehunen hazkundea areagotzen zela ikusi zen, eta giza kartilagoaren antzeko propietate mekanikoak dituen hidrogela sortzen $[59,60]$.

\section{ONDORIOAK}

Azken urteotan, polisakaridoetan oinarritutako hidrogelen ikerkuntzak etorkizunean garrantzi handia hartuko duten biomaterialei zabaldu dizkie ateak. Alde batetik, material biobateragarriak dira, horien iturri natural eta berriztagarriak direla eta, eta horrek gure gorputzarekin bateragarritasuna bermatzen du, bioaktibitate maila altuak mantenduz. Bestetik, estimuluen aurrean erantzuteko gaitasunak material adimentsuen sorkuntza bultzatzen $\mathrm{du}$, gorputzaren seinaleak detektatu eta horiei erantzuteko gai diren materialak garatzeko. Horrez gain, gelek duten ur kantitate handiei esker, giza gorputzaren antzeko materialak lortzen dira, eta, hala, inplanteen egokitzapena errazten. Bukatzeko, gelifikazio prozesua hainbat estimulu fisikoren bitartez eragin daitekeenez, in-situ gelifikazioa baimentzen duten hidrogelak lortu dira, eta erosoagoak diren aplikazio injektagarriak bultzatu.

Aplikazioei dagokienez, polisakaridoetan oinarritutako hidrogelen biobateragarritasun, moldagarritasun eta sentikortasunari esker, biomedikuntzan garrantzia handia daukate. Farmakoen Horniketara Bideratutako Sistemei (DDS ingelesez) dagokienez, konposatuen askapen-ratio eraginkorragoak lortu dira hidrogelen erabilerari esker, eta, horrez gain, hainbat estimuluren aurren erantzuteko gai diren materialak garatu dira, eta farmakoen horniketa zehatzagoa bermatu. Ehun-ingeniaritzan, bestetik, giza ehunen hazkundea ahalbidetzen duten hidrogeletan oinarritutako matrize zelularrak garatu dira, eta biobateragarritasunari esker gorputzera moldatzeko gai direnek bizi kalitatea nabarmen hobetu dute.

Gaur egun erronka handiena iturri naturalek ezartzen dituzten mugak gainditzea da, horiek sintetizazio prozesuan sartzen dituzten ezjakintasunak ekidin eta prozesu kontrolatuagoak lortu ahal izateko.

\section{ESKER ONAK}

Lan hau Eusko Jaurlaritzaren IKASIKER beka baten laguntzarekin egin ahal izan du Mikel Mendibek ZIBIO ikertalde kontsolidatuaren baitan 
(IT-927-16) (UPV/EHU; GIC/152). Eskerrak eman nahi dizkiogu Xabier Larrañaga ZIBIO iker-taldeko kideari laborategian emandako laguntzagatik.

\section{BIBLIOGRAFIA}

[1] UteCh, S., BocCaCcinI, A. R. 2016. «A review of hydrogel-based composites for biomedical applications: enhancement of hydrogel properties by addition of rigid inorganic fillers». Journal of Materials Science, 51, 271-310.

[2] Thakur, S., Thakur, V. K., Arotiba, O. A.Springer, Singapore 2018 , pp. 29-50.

[3] Buwalda, S. J., Boere, K. W. M., Dijkstra, P. J., Fejuen, J., Vermonden, T., HenNinK, W. E. 2014. «Hydrogels in a historical perspective: From simple networks to smart materials». Journal of Controlled Release, 190, 254273.

[4] Bahram, M., Mohseni, N., Moghtader, M.Emerging Concepts in Analysis and Applications of Hydrogels. InTech 2016.

[5] Sandoval, C. n.d. «Polisacaridos».

[6] A. Lejardi, I. GARMEndia, JR SARASUA «Polivinil alkohol/Kitosano sistemaren nahaskortasun egoeraren hobekuntza», 37-4. ISBN: 978-84-9082-005-6. Materialen Zientzia eta Teknologia II. Kongresua, Donostia 2014, Euskal Herriko Unibertsitateko argitalpen zerbitzua (UPV/EHU).

[7] Gu, Z., Huang, K., Luo, Y., Zhang, L., Kuang, T., Chen, Z., Liao, G. 2018. «Double network hydrogel for tissue engineering». Wiley Interdisciplinary Reviews: Nanomedicine and Nanobiotechnology, 10, e1520.

[8] IsPizua, I. OlabarRieta, JR SARAsua.« Polimero naturalen (kitosanoa, esne-gazuraren proteina isolatua) eta polimero sintetikoen (PCL) nahasteaz lortutako film biodegradagarrien hesi-ezaugarriak eta portaera mekanikoa», Ekaia 19, $31-47$ (2005).

[9] Ahsan, S. M., Thomas, M., Reddy, K. K., Sooraparaju, S. G., Asthana, A., BHATNAGAR, I. 2018. «Chitosan as biomaterial in drug delivery and tissue engineering». International Journal of Biological Macromolecules, 110, 97-109.

[10] Roberts, G. A. F.Chitin Chemistry. Macmillan Education UK, London 1992, pp. 1-53.

[11] Carreira, A. S., Gonçalves, F. A. M. M., Mendonça, P. V., Gil, M. H., Coelho, J. F. J. 2010. «Temperature and $\mathrm{pH}$ responsive polymers based on chitosan: Applications and new graft copolymerization strategies based on living radical polymerization». Carbohydrate Polymers, 80, 618-630.

[12] Sogias, I. A., Williams, A. C., KhutoryanskiY, V. V. 2008. «Why is chitosan mucoadhesive?». Biomacromolecules, 9, 1837-1842.

[13] Lejardi, A., Hernández, R., Criado, M., Santos, J. I., Etxeberria, A., Sarasua, J. R., Mijangos, C. 2014. «Novel hydrogels of chitosan and 
poly(vinyl alcohol)-g-glycolic acid copolymer with enhanced rheological properties». Carbohydrate Polymers, 103, 267-273.

[14] Chang, C., Zhang, L. 2011. «Cellulose-based hydrogels: Present status and application prospects». Carbohydrate Polymers, 84, 40-53.

[15] Li, S. N., Li, B., Gong, L. X., Yu, Z. R., Feng, Y., JiA, D., Zhou, Y., Tang, L. C. 2019. «Enhanced mechanical properties of polyacrylamide/chitosan hydrogels by tuning the molecular structure of hyperbranched polysiloxane». Materials and Design, 162, 162-170.

[16] Huang, J., Best, S. M., Bonfield, W., Brooks, R. A., Rushton, N., JayaSINGHE, S. N., EDIRISINGHE, M. J.Journal of Materials Science: Materials in Medicine. J Mater Sci Mater Med 2004, pp. 441-445.

[17] Huang, Y., Zhang, X., Wu, A., Xu, H. 2016. «An injectable nano-hydroxyapatite (n-HA)/glycol chitosan (G-CS)/hyaluronic acid (HyA) composite hydrogel for bone tissue engineering». RSC Advances, 6, 33529-33536.

[18] Park, K. M., Lee, S. Y., Joung, Y. K., NA, J. S., LeE, M. C., Park, K. D. 2009. «Thermosensitive chitosan-Pluronic hydrogel as an injectable cell delivery carrier for cartilage regeneration». Acta Biomaterialia, 5, 1956-1965.

[19] Hong, Y., Gong, Y., GaO, C., SHEn, J. 2008. «Collagen-coated polylactide microcarriers/chitosan hydrogel composite: Injectable scaffold for cartilage regeneration». Journal of Biomedical Materials Research - Part A, 85, 628637.

[20] Aravamudhan, A., Ramos, D. M., Nada, A. A., Kumbar, S. G.Natural and Synthetic Biomedical Polymers. Elsevier Inc. 2014, pp. 67-89.

[21] Fenn, S. L., Miao, T., Scherrer, R. M., Oldinski, R. A. 2016. «Dual-CrossLinked Methacrylated Alginate Sub-Microspheres for Intracellular Chemotherapeutic Delivery». ACS Applied Materials and Interfaces, 8, 1777517783.

[22] Summa, M., Russo, D., Penna, I., Margaroli, N., Bayer, I. S., Bandiera, T., Athanassiou, A., Bertorelli, R. 2018. «A biocompatible sodium alginate/povidone iodine film enhances wound healing». European Journal of Pharmaceutics and Biopharmaceutics, 122, 17-24.

[23] Kamoun, E. A., Kenawy, E. R. S., Chen, X. 2017. «A review on polymeric hydrogel membranes for wound dressing applications: PVA-based hydrogel dressings». Journal of Advanced Research, 8, 217-233.

[24] Saarai, A., Sedlacek, T., Kasparkova, V., Kitano, T., Saha, P. 2012. «On the characterization of sodium alginate/gelatine-based hydrogels for wound dressing». Journal of Applied Polymer Science, 126, E79-E88.

[25] LeE, K. Y., Mooney, D. J. 2012. «Alginate: Properties and biomedical applications». Progress in Polymer Science (Oxford), 37, 106-126.

[26] Axpe, E., OYEN, M. 2016. «Applications of Alginate-Based Bioinks in 3D Bioprinting». International Journal of Molecular Sciences, 17, 1976.

[27] Liu, Q., Li, Q., Xu, S., Zheng, Q., CAO, X. 2018. «Preparation and Properties of 3D Printed Alginate-Chitosan Polyion Complex Hydrogels for Tissue Engineering». Polymers, 10, 664. 
[28] Kabir, S. M. F., Sikdar, P. P., Haque, B., Bhuiyan, M. A. R., Ali, A., ISLAM, M. N. 2018. «Cellulose-based hydrogel materials: chemistry, properties and their prospective applications». Progress in Biomaterials, 7 , 153-174.

[29] Ciolacu, D., Oprea, A. M., Anghel, N., Cazacu, G., Cazacu, M. 2012. «New cellulose-lignin hydrogels and their application in controlled release of polyphenols». Materials Science and Engineering: C, 32, 452-463.

[30] Fu, L. H., QI, C., MA, M. G., WAN, P. 2019. «Multifunctional cellulose-based hydrogels for biomedical applications». Journal of Materials Chemistry $B, 7,1541-1562$.

[31] K, P. 2006. «Development of carboxymethyl cellulose acrylate for various biomedical applications.». Biomedical materials (Bristol, England), 1, $85-91$.

[32] An, G. S., Han, J. S., Shin, J. R., Chae, D. H., Hur, J. U., Park, H. Y., JunG, Y. G., CHOI, S. C. 2018. «In situ synthesis of Fe3O4@SiO2 core-shell nanoparticles via surface treatment». Ceramics International, 44, 1223312237.

[33] Radhakrishnan, A., Jose, G. M., Kurup, M. 2015. «PEG-penetrated chitosan-alginate co-polysaccharide-based partially and fully cross-linked hydrogels as ECM mimic for tissue engineering applications». Progress in Biomaterials, 4, 101-112.

[34] Shen, X., Shamshina, J., Berton, P., ... G. G.-G., 2016, undefined. n.d. «Hydrogels based on cellulose and chitin: fabrication, properties, and applications». pubs.rsc.org.

[35] Marler, J. J., Upton, J., LANGer, R., VACANTI, J. P. 1998. «Transplantation of cells in matrices for tissue regeneration». Advanced Drug Delivery Reviews, 33, 165-182.

[36] OKano, T., Kikuchi, A., SAKurai, Y., ... Y. T.-J. OF CONTROLled, 1995, unDEFINED. n.d. «Temperature-responsive poly ( $\mathrm{N}$-isopropylacrylamide) as a modulator for alteration of hydrophilic/hydrophobic surface properties to control activation/inactivation of». Elsevier.

[37] Chen, J., Chen, L., Xie, F., Li, · Xiaoxi. n.d. Drug Delivery Applications of Starch Biopolymer Derivatives.

[38] Reis, A. V., Guilherme, M. R., Moia, T. A., Mattoso, L. H. C., Muniz, E. C., TAMBourgi, E. B. 2008. «Synthesis and characterization of a starch-modified hydrogel as potential carrier for drug delivery system». Journal of Polymer Science, Part A: Polymer Chemistry, 46, 2567-2574.

[39] Biduski, B., Silva, W. M. F. Da, Colussi, R., Halal, S. L. DE M. El, Lim, L. T., Dias, Á. R. G., Zavareze, E. DA R. 2018. «Starch hydrogels: The influence of the amylose content and gelatinization method». International Journal of Biological Macromolecules, 113, 443-449.

[40] Ismail, H., Irani, M., Ahmad, Z. 2013. «Starch-based hydrogels: Present status and applications». International Journal of Polymeric Materials and Polymeric Biomaterials, 62, 411-420. 
[41] Harling, S., Schwoerer, A., Scheibe, K., Daniels, R., Menzel, H. 2010. «A new hydrogel drug delivery system based on Hydroxyethylstarch derivatives». Journal of Microencapsulation, 27, 400-408.

[42] SADEGHI, M. n.d. «Turk J Chem Synthesis of starch-g-poly(acrylic acid-co2-hydroxy ethyl methacrylate) as a potential $\mathrm{pH}$-sensitive hydrogel-based drug delivery system», DOI: 10.3906/kim-1103-27.

[43] SÁ-Lima, H., Caridade, S. G., Mano, J. F., Reis, R. L. 2010. «Stimuli-responsive chitosan-starch injectable hydrogels combined with encapsulated adipose-derived stromal cells for articular cartilage regeneration». Soft Matter, 6, 5184-5195.

[44] Ngoenkam, J., Faikrua, A., Yasothornsrikul, S., Viyoch, J. 2010. «Potential of an injectable chitosan/starch/ $\beta$-glycerol phosphate hydrogel for sustaining normal chondrocyte function». International Journal of Pharmaceutics, 391, 115-124.

[45] González, K., García-Astrain, C., Santamaria-Echart, A., Ugarte, L., AvÉrous, L., EceizA, A., GABILONDO, N. 2018. «Starch/graphene hydrogels via click chemistry with relevant electrical and antibacterial properties». Carbohydrate Polymers, 202, 372-381.

[46] Campo, V. L., Kawano, D. F., Silva, D. B. Da, Carvalho, I. 2009. «Carrageenans: Biological properties, chemical modifications and structural analysis - A review». Carbohydrate Polymers, 77, 167-180.

[47] Zhu, M., Ge, L., Lyu, Y., Zı, Y., Li, X., Li, D., Mu, C. 2017. «Preparation, characterization and antibacterial activity of oxidized $x$-carrageenan». Carbohydrate Polymers, 174, 1051-1058.

[48] Yuan, H., Zhang, W., Li, X., Lü, X., Li, N., GaO, X., Song, J. 2005. «Preparation and in vitro antioxidant activity of $x$-carrageenan oligosaccharides and their oversulfated, acetylated, and phosphorylated derivatives». Carbohydrate Research, 340, 685-692.

[49] Yegappan, R., Selvaprithiviraj, V., Amirthalingam, S., Jayakumar, R. 2018. «Carrageenan based hydrogels for drug delivery, tissue engineering and wound healing». Carbohydrate Polymers, 198, 385-400.

[50] Hariharan, M., Wheatley, T. A., Price, J. C. 1997. «Controlled-release tablet matrices from carrageenans: Compression and dissolution studies». Pharmaceutical Development and Technology, 2, 383-393.

[51] Maderuelo, C., Zarzuelo, A., Lanao, J. M. 2011. «Critical factors in the release of drugs from sustained release hydrophilic matrices». Journal of Controlled Release, 154, 2-19.

[52] Rasool, A., Ata S., Islam, A., Ullah Khan, R.M, 2019. «Fabrication of novel carrageenan based stimuli responsive onjectable hydrogels for controlled release of cephradine». RSC Advances journal,9, 22-19.

[53] Bonferoni, M. C., Chetoni, P., Giunchedi, P., Rossi, S., Ferrari, F., BurgaLASSI, S., CARAMELla, C. 2004. «Carrageenan-gelatin mucoadhesive systems for ion-exchange based ophthalmic delivery: In vitro and preliminary in vivo studies». European Journal of Pharmaceutics and Biopharmaceutics, 57, 465-472. 
[54] Briones, A. V., SAto, T. 2010. «Encapsulation of glucose oxidase (GOD) in polyelectrolyte complexes of chitosan-carrageenan». Reactive and Functional Polymers, 70, 19-27.

[55] Kim, I. Y., Iwatsuki, R., Kikuta, K., Morita, Y., Miyazaki, T., Ohtsuki, C. 2011. "Thermoreversible behavior of $x$-carrageenan and its apatite-forming ability in simulated body fluid». Materials Science and Engineering $C$, 31, 1472-1476.

[56] Feng, W., Feng, S., Tang, K., He, X., Jing, A., Liang, G. 2017. «A novel composite of collagen-hydroxyapatite/kappa-carrageenan». Journal of Alloys and Compounds, 693, 482-489.

[57] Bhattacharyya, S., Liu, H., Zhang, Z., Jam, M., Dudeja, P. K., Michel, G., Linhardt, R. J., Tobacman, J. K. 2010. «Carrageenan-induced innate immune response is modified by enzymes that hydrolyze distinct galactosidic bonds». Journal of Nutritional Biochemistry, 21, 906-913.

[58] Popa, E. G., Carvalho, P. P., Dias, A. F., Santos, T. C., Santo, V. E., Marques, A. P., Viegas, C. A., Dias, I. R., Gomes, M. E., Reis, R. L. 2014. «Evaluation of the in vitro and in vivo biocompatibility of carrageenan-based hydrogels». Journal of Biomedical Materials Research Part A, 102, 40874097.

[59] DeLise, A. M., Fischer, L., TuAn, R. S. 2000. «Cellular interactions and signaling in cartilage development». Osteoarthritis and Cartilage, 8, 309-334.

[60] Popa, E. G., Caridade, S. G., Mano, J. F., Reis, R. L., Gomes, M. E. 2015. «Chondrogenic potential of injectable $x$-carrageenan hydrogel with encapsulated adipose stem cells for cartilage tissue-engineering applications». Journal of Tissue Engineering and Regenerative Medicine, 9, 550-563.

[61] An, G. S., Han, J. S., Shin, J. R., Chae, D. H., Hur, J. U., Park, H. Y., JunG, Y. G., CHOI, S. C. 2018. «In situ synthesis of Fe3O4@SiO2 core-shell nanoparticles via surface treatment». Ceramics International, 44, 1223312237.

[62] Hamedi, H.; Moradi, S.; Hudson, S.M.; Tonelli, A.E. « Chitosan based hydrogels and their applications for drug delivery in wound dressings: a review». Carbohydr. Polym., 199 (2018), pp. 445-460.

[63] Abasalizadeh, F., Moghaddam, S., Alizadeh, E. 2020.« Alginate-based hydrogels as drug delivery vehicles in cancer treatment and their applications in wound dressing and 3D bioprinting». Journal of Biological Engineering, 14, 8 . 